\begin{tabular}{|l|l|c|c|}
\hline Eiszeitalter u. Gegenwart & $\mathbf{3 0}$ & $\begin{array}{c}253-259 \\
3 \mathrm{fig} .\end{array}$ & Hannover 1980 \\
\hline
\end{tabular}

\title{
Paleogeographic Interpretation of a Peat Layer at Torson di Sotto (Lagoon of Venice, Italy) *)
}

\author{
Paolo A. Pirazzoli, Nadine Planchais, Marie Rosset-Moulinier \\ \& JeAN ThOMMERET $*$ )
}

Paleogeography, peat, stratiform deposit, lagoon, sea level, intertidal sedimentation, regression, transgression, interpretation, core cuttings, pollens (Quercus, Alnus), foraminiferal fauna, C-14 dating, Holocene, Palaeosalinity, freshwater environment, brackish water. Veneto (Lagoon of Venice).

A bstract: A $3.3 \mathrm{~m}$ long core from the central part of the lagoon of Venice has revealed a peat layer between $1.3 \mathrm{~m}$ and $2.0 \mathrm{~m}$ below mean sea level. Pollen analysis indicates the predominance of Quercus and Alnus and the existence of a transgressive phase: the base of the peat (dated $1730 \pm 80 \mathrm{y} . \mathrm{BP}$ ) was formed in a soft water environment, and the upper part (dated $1140 \pm 80 \mathrm{y} . \mathrm{BP})$ in a brackish one.

Foraminifera analysis indicate that transgression has preceded a regression. The whole sequence is, from bottom to top (Fig. 3): (1) an oligohaline to mesohaline environment (from - 3.3 to $-2.5 \mathrm{~m}$ ) with very abundant forams; (2) a soft water environment (from -2.5 to $-2.0 \mathrm{~m}$ ); (3) the $0.7 \mathrm{~m}$ thick peat layer, becoming gradually brackish; (4) a mesohaline environment (above $-1.3 \mathrm{~m})$.

Correlation with neighbouring localities (Fig. 1) indicates that similar phenomena occurred at the same time in the central part of the lagoon, but not in its northern part. This regression-transgression sequence is ascribed to an increased rainfall period, at about the end of Roman times, which would have resulted in the flooding and a change in the course of several rivers; the hydrologic equilibrium in this marshy area would have been modified temporarily.

Over the past 100 years, the transgression has accelerated, largely as a result of anthropic works. The "barene" are now eroding and disappearing quickly (Fig. 2). They are being replaced by wide sea-water basins.

\section{[Paläogeographische Interpretation einer Torflage bei Torson di Sotto (Lagune von Venedig, Italien)]}

Kurzfassung: Ein 3,3 m langer Kern aus dem zentralen Bereich der Lagune von Venedig enthielt eine Torflage zwischen 1,3 und 2,0 m unter dem mittleren Meeresspiegel. Pollenanalysen zeigen ein Vorherrschen von Quercus und Alnus und eine transgressive Phase an: der untere Teil des Torfes (nach ${ }^{14} \mathrm{C}$-Daten $1730 \pm 80$ v.h.) ist in einem Süßwasser-Environment gebildet worden, der obere Teil (nach ${ }^{14} \mathrm{C}-$ Daten $1140 \pm 80$ v.h.) in einem brackischen. Foraminiferenanalysen zeigen an, daß der Transgression eine Regression vorangegangen ist. Die gesamte Abfolge enthält von unten nach oben (Abb. 3): (1) ein oligohalines bis mesohalines Environment (von $-3,3$ bis $-2,5 \mathrm{~m}$ ) mit sehr zahlreichen Foraminiferen; (2) ein Süßwasser-Environment (von $-2,5$ bis $-2,0 \mathrm{~m})$; (3) die $0,7 \mathrm{~m}$ mächtige Torflage, die fortschreitend brackisch wird; (4) ein mesohalines Environment (oberhalb $-1,3 \mathrm{~m}$ ).

*) Field-Work was supported by Centre National de la Recherche Scientifique (contrat hors convention A 6412) and was carried out in collaboration with L. Alberotanza and V. Favero. Oceanographic vessel "Umberto D'Ancona" of the Consiglio Nazionale delle Ricerche was available for these operations.

**) Adresses of the authors: P.A.Pirazzoli, C.N.R.S. (E.R.A. 867) and Laboratoire de Géomorphologie de l'E.P.H.E., 1 rue Maurice Arnoux, 92120-Montrouge, France (Field-work, geomorphology, and coordination). - N.Planchais, C.N.R.S., Laboratoire de Palynologie de l’U.S.T.L., Place Eugène Bataillon, 34060-Montpellier Cedex, France (Pollen analysis). - M. Rosset-Moulinier, Laboratoire de Biologie-Géologie de l'E.N.S., 1 rue M. Arnoux, $92120-$ Montrouge, France (Foraminifera). - J. Thommeret, Centre Scientifique de Monaco, Laboratoire de Radioactivité appliquée, Avenue Saint-Martin, Principauté de Monaco (Radiometric dating). 
Korrelationen mit benachbarten Lokalitäten (Abb. 1) weisen darauf hin, daß vergleichbare Erscheinungen zu gleicher Zeit im Zentralteil der Lagune, aber nicht in ihrem Nordteil, aufgetreten sind. Diese Regressions-Transgressions-Abfolge wird auf eine Periode erhöhter Niederschläge um das Ende der Römerzeit zurückgeführt, die zur Überflutung und zu einer Verlagerung des Laufes zahlreicher Flüsse geführt hat; dabei ist das ökologische Gleichgewicht dieses Marschengebietes zeitweilig verändert worden.

Im Verlauf der vergangenen 100 Jahre hat sich die Transgression beschleunigt, überwiegend infolge anthropogener Eingriffe. Die "Barene“ werden jetzt erodiert und verschwinden rasch (Abb. 2). Sie werden durch weite Meerwasserbecken eingenommen.

\section{Introduction}

Torson di Sotto $\left(45^{\circ} 20^{\prime} 55^{\prime} \mathrm{N}-12^{\circ} 13^{\prime} 46^{\prime \prime} \mathrm{E}\right)$ is a small islet of about 1,000 square meters in the Venice Lagoon, practically in the centre of the Malamocco basin. Its present situation below the "barene" limit ("barene" being the local name for the tidal flats) is of somewhat recent origin.

Four centuries ago the Brenta River mouth opened into the lagoon close to that locality. Two centuries later the "Casone" of Torson di Sotto was entirely surrounded by the "barene". As a result of the shrinking of this "barene" by erosion Torson di Sotto became an islet towards the end of the last century; it could well disappear in the coming decades.

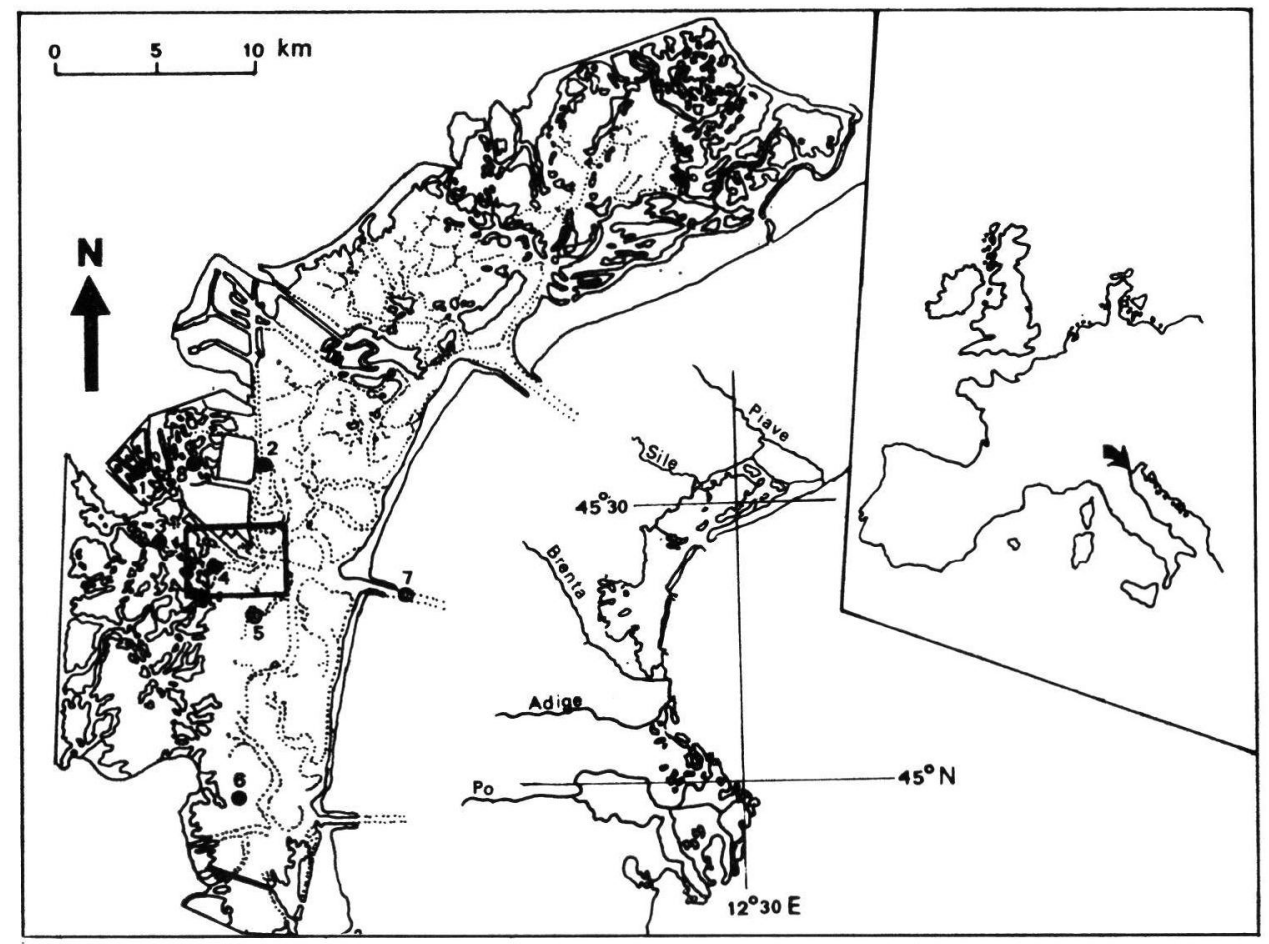

Fig. 1: Location of the lagoon sites mentioned in the text: (1) Fosso del Sorgo; (2) Motte di Volpego; (3) Torson di Sopra; (4) Torson di Sotto; (5) Motta del Cornio Vecchio; (6) Barena di Ca' Manzo; (7) Malamocco Pass and entrance of the oil-transport channel; (8) Laghi Teneri. 
The progressive erosion of the "barene" is a consequence not only of the reduction of the river sedimentary supply, after the deviation of the Brenta R. out of the lagoon, but also of the damming up and the progressive deepening of the Pass of Malamocco, directly opposit to Torson di Sotto and $8 \mathrm{~km}$ away. The depth of this inlet, which was about 4 or 5 meters in 1811, increased after the building of the two embankments to 8-9 m by 1901 and, after the digging of the Oil-transport channel between 1966 and 1969, to more than $15 \mathrm{~m}$ at the present time (Pirazzoli 1974). The local tidal range $\left(2 \mathrm{HM}_{2}+2 \mathrm{HS}_{2}\right)$ was $0.65 \mathrm{~m}$ in 1938 (Polli 1950) and increased to about $0.75 \mathrm{~m}$ in 1973 (Goldman et al. 1975).

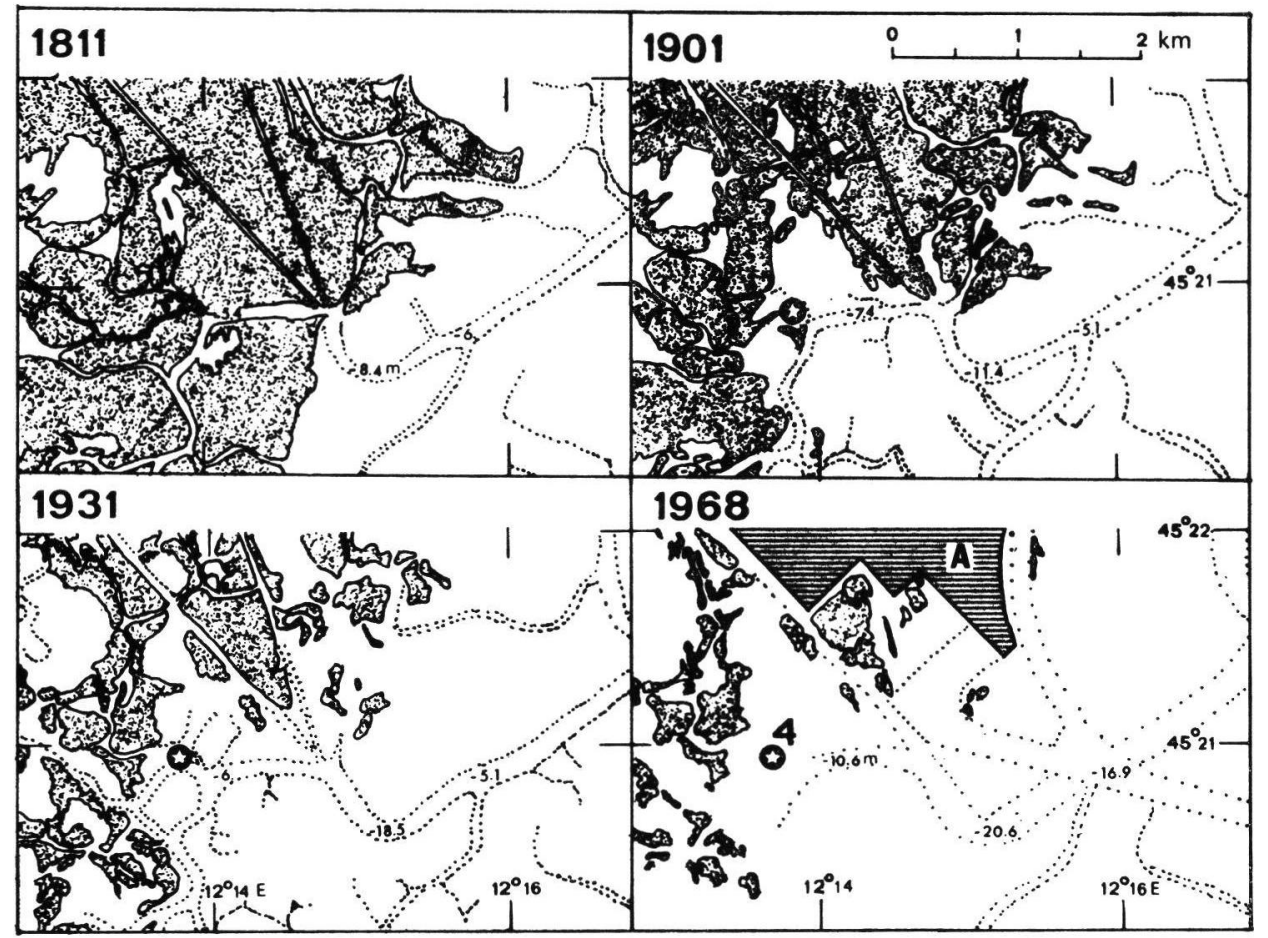

Fig. 2: The "barene" (local tidal flats) have almost disappeared near Torson di Sotto between 1811 and 1968. (A) man-made embankments; (4) Torson di Sotto.

The salinity which today is about $37-38 \%$ in the Adriatic, 30\% in the openlagoon and 20-25\% (or somewhat less) in the "Valli", must have been much lower in former times. Indeed if the present flow of the small rivers opening in the lagoon could reach a maximum of $650 \mathrm{~m}^{3} \mathrm{~s}^{-1}$ (Cavazzoni 1973), former flows of rivers in spate (the Piave, Sile and Brenta Rivers, as well as some tributaries of the Adige River) were certainly many times more important. The area of Torson di Sotto, in particular, would have been strongly dependent on the influence of the Brenta River at the time when its delta discharged in this region.

\section{Field work}

In the course of a preliminary investigation of the lagoonal Holocene sediments, a coring of $3.3 \mathrm{~m}$ long was made in 1977 near the northern border of Torson di Sotto. A $40 \mathrm{~mm}$ diameter Dachnowsky sampler was used. There core showed the following 
stratigraphical succession: (depths are reported with respect to the mean sea level = m.s.1.) (Fig. 3).

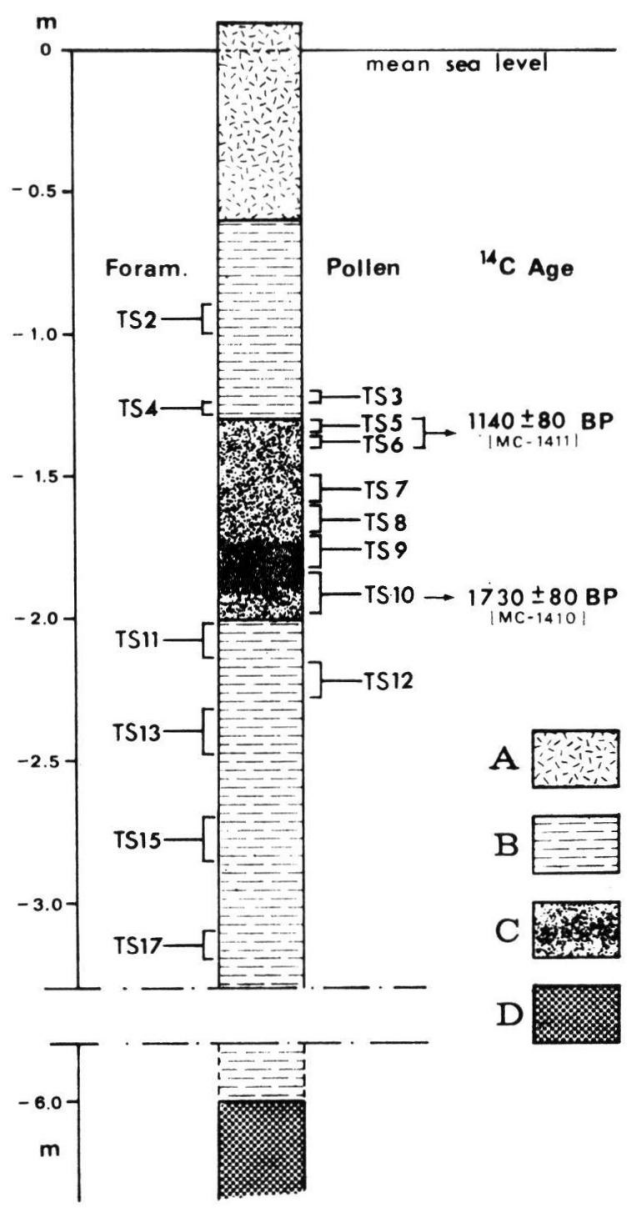

Fig. 3: Location of the analysed samples and stratigraphy of the Torson di Sotto core. (A) reworked silt; (B) silt; (C) peat; (D) continental layers.

- From surface to $-0.6 \mathrm{~m}$ : reworked oozes of a green to mustard-yellow colour, probably coming from the neighbouring channel draggings in the lagoon.

- From -0.6 to $-1.3 \mathrm{~m}$ : muddy clay of grey colour with some rare vegetal remains.

- From -1.3 to $-2.0 \mathrm{~m}$ : peat, turning to a dark-black colour between -1.7 to $-1.8 \mathrm{~m}$.

- From -2.0 to $-3.3 \mathrm{~m}$ : greyish clayey mud.

Another and deeper coring showed that the estuarine or lagoonal silts mixed with some traces of peat, sand and, occasionally, with fossils, were found down to about $-6.0 \mathrm{~m}$ depth. At this depth they were replaced by a clay which appeared to be of continental origin. 


\section{Pollen analysis}

Seven samples were analysed (Fig. 3), but two of them (TS9 and TS10) taken from the humified bottom part of the peat contained hardly any pollens. Samples TS3, TS5, TS7, TS8 were abundant in Chenopodiaceae and can accordingly be considered as brackish-water deposits. Sample TS12, a Phragmite mud, may on the other hand be considered as a soft-water deposit because of the important contribution of Cyperaceae, Graminae and pollens of the type Typha-Sparganium.

The thermophile pollens of anthropic origin, Juglans, Olea, and Vitis, are consistent although rare. In sample TS12 the absence of some species of anthropic origin (Castanea, Juglans) which are by contrast found in the upper levels, lead one to believe that this sample was deposited before the Roman occupation (Horowitz 1966-1967).

\section{Foraminifera analysis}

Six samples were analysed (two above and four beneath the peat layer). The results follow.

TS2 - Few forams were found. Those observed were Ammonia tepida, Protelphidium paralium (= Nonion depressulum for Cita and Premoli-Silva 1967) and Buccella (= Ammonia) perlucida. Cita and Premoli-Silva consider that this association corresponds to a typical lagoonal environment, whereas Levy (1971) considers it mesohaline. The presence of some Miliolidae suggests that the transport of littoral marine material is involved.

TS4 - Forams rare: Ammonia tepida, Protelphidium paralium and Trochammina inflata. This last species is typical of a halophile vegetation zone (LUTZE 1968, Murray 1971).

TS11 and TS13 - No forams.

TS15 - Very abundant forams: Ammonia tepida (about $70 \%$ ), Protelphidium paralium (about 30\%) and some rare Buccella perlucida and Elphidium decipiens. Oligo to mesohaline environment.

TS17 - Very abundant forams: Ammonia tepida (90\%), Protelphidium paralium, Ammobaculites agglutinans, Elphidium decipiens and Buccella perlucida. Oligo to mesohaline environment.

\section{Radiometric datations}

We were able to date the upper and lower part of the peat layer using the ${ }^{14} \mathrm{C}$ method. A combination of samples TS5 and TS6, collected between $-1.3 \mathrm{~m}$ and $-1.4 \mathrm{~m}$, yielded an apparent age of $1140 \pm 80$ y. BP (MC-1411). Sample TS10, collected at about $-1.90 /-1.95 \mathrm{~m}$, yielded an age of $1730 \pm 80 \mathrm{y}$. BP (MC-1410) (no correction for age was applied).

\section{Some correlations}

A change in the paleogeographic conditions of Torson di Sotto, characterized by a regressive followed by a transgressive marine phase, may be infered from pollens and forams found from TS17 to TS2. This oscillation is in no way an isolated phenomenon.

(1) At Motta del Cornio Vecchio (Fig. 1, Loc. 5) our coring-device encountered between -1.8 and $-2.0 \mathrm{~m}$ a peat layer similar to that of Torson di Sotto.

17 Eiszeitalter u. Gegenwart 
(2) Near the northern limit of Ca' Manzo (Loc. 6) a peat layer is found between -2.0 and $-2.5 \mathrm{~m}$. Just above and below this layer the forams are rare (some Ammonia tepida, Protelphidium paralium, Buccella perlucida) or absent.

(3) In a core from Motte di Volpego (Loc. 2), Ascoli (1966-1967) observed between -5.09 and $-5.65 \mathrm{~m}$, with respect to m.s.l., the presence of blackish clays of high organic content and vegetal remains but entirely free of fossil remains. These layers were interpreted by Ascoli as evidence of a very short continental phase of a lacustrine environment type. In the same core, a marine shell found at $0.5 \mathrm{~m}$ beneath the clay layer was dated at $1708 \pm 85 \mathrm{y} . \mathrm{BP}$ (Bonatti 1968).

(4) At Fosso del Sorgo (Loc. 1), Marcello and Spada (1968) mention the existence of peat layers from -1.35 to $-1.85 \mathrm{~m}$ relative to m.s.l. These deposits, which represent a continental marsh environment, cover soft-water sediments and are themselves topped by a "barene" formation. Tree stumps (Alnus, Fraxinus) were observed close by at about $1 \mathrm{~m}$ depth. Other tree stumps, probably a part of the same forest, were dated at $1140 \pm 45 \mathrm{y}$. BP at Torson di Sopra (Loc. 3) and at $1515 \pm 85$ y. BP at Laghi Teneri (Loc. 8).

It appears that these peat layers, situated at various depths, do not differ much from the peat of Torson di Sotto in their ${ }^{14} \mathrm{C}$ ages.

\section{Discussion and conclusion}

The period between 450 and $650 \mathrm{AD}$ appears to have been very rainy in Venetia (MARCello 1963). It was marked by an important hydrologic event: the flooding of 589 AD, described by Paulus Diaconus. This changed the course of several rivers, among them the Brenta and Adige ${ }^{1}$ ). Such powerful was the intensity of the flooding that the town of Julia Concordia, $30 \mathrm{~km}$ to the N-E of the Venetian laguna was destroyed entirely and was left covered by a soft water marsh (Marcello and Comel 1963).

Peat deposits seem to have developed mainly in the central and southern part of the Venetian lagoon, at the former mouth of the Brenta River. In the northern part of the lagoon, on the other hand, the rush of soft water appears to have been less abundant than in central or southern part. The lithology of 35 cores (Alberotanza et al. 1977) does not show the regressive-transgressive oscillation observed in the area of Torson di Sotto, even though there is evidence that brackish waters were present as far back as the Roman epoch. This regressive-transgressive oscillation is not therefore of eustatic origin.

Taking account of all available data, an interpretative sketch of the successive events may be outlined.

Towards the end of the Roman epoch, the lack of maintenance and, probably, an increase in the rainfall, provoked in Venetia some hydrographic disorders around the lagoonal outlets. The level of the soft water layer must have risen, particularly in the vicinity of the water streams. The paludal marshes were than able to extend; the influence of tidal action down-stream was limited, fluvial sediments were trapped, thus giving rise to the formation and deposit of the littoral peats.

At the same time, the compaction of lagoonal Holocene sediments, already some metres thick, was continuing slowly. This compaction was particularly important for peat layers, although it varied from place to place. It probably had the added effect of a slight

1) Hist. L a ngob., III, 23: "Eo tempore fuit aquae diluvium in finibus Venetiarum et Liguriae, seu ceteris regionibus Italiae, quale post Noë tempus creditur non fuisse. Factae sunt lavinae possessionum, seu villarum, hominumque pariter et animantium magnus interitus. Destricta sunt itinera, dissipatae sunt viae...". 
rising of the sea-level, which in this area does not appear to have reached a level higher than that which exists at present (PIRAzzoli 1973).

Nature was only overcome at the end of the 1st millennium of our era, when the rising State of Venice ordered the digging of channels for drainage or navigation and when the principal river streams were progressively deviated away from the Lagoon. Brackish environments slowly gained the upper hand and stagnant soft waters disappeared; the peat was recovered by a vegetation more and more halophile.

After the improvement of the pass of Malamocco, one century ago, the transgressive phase accelerated near Torson di Sotto. Over several decades the transgression became more and more rapid, as a result of subsidences of anthropic origin and of the progressive deepening of the channel inlet. The resulting increase of the tidal range, the concomitant increase in the tidal current power, and the polluting action of Man (PIrazzoli 1978) have accentuated the erosional phenomena. The present transgressive stage leads to a rapid retreat of the "barene", and leaves in their place water basins which, when they are not obscured by pollution, are less and less lagoonal and more and more marine in their characteristics.

\section{References}

Alberotanza, L., Serandrei Barbero, R., Favero, V. (1977): I sedimenti olocenici della laguna di Venezia (bacino settentrionale). - Boll. Soc. Geol. It., 96: 243-269; Rom.

AscolI, P. (1966-67): Ostracodi olocenici continentali e salmastri di un pozzo perforato nella laguna di Venezia. - Mem. Biogeogr. Adriatica, VII: 53-149; Venezia.

Bonatti, E. (1968): Late-Pleistocene and postglacial stratigraphy of a sediment core from the lagoon of Venice (Italy). - Mem. Biogeogr. Adriatica, VII, Suppl.: 9-26; Venezia.

Cavazzoni, S. (1973): Acque dolci nella laguna di Venezia. - C.N.R., Lab. Dinamica Grandi Masse, Rapp. Tecn., 64: 33 p.; Venezia.

Cita, M. B. \& Premoli Silva, I. (1966-67): Sui foraminiferi incontrati in un pozzo perforato nella laguna di Venezia. - Mem. Biogeogr. Adriatica, VII: 29-52; Venezia.

Goldmann, A., Rabagliati, R. \& Sgunzzero, P. (1975): Characteristics of the tidal wave in the Lagoon of Venice. - IBM Italia, Technical Report CR V 009-513-3539, 52 p.; Venecia.

Новоwitz, A. (1966-67): Palynological studies in the lagoon of Venice. - Mem. Biogeogr. Adriatica, VII: 17-27; Venezia.

Levy, A. (1971): Eaux saumâtres et milieux margino-littoraux. - Rev. Géogr. phys. Géol. dyn., 13, 3: 269-278; Paris.

Lutze, G. F. (1968): Jahresgang der Foraminiferen-Fauna in der Bottsand-Lagune (westliche Ostsee). - Meyniana, 18: 13-30; Kiel.

Marcello, A. (1963): Lacuna floristica del Veneziano e sue condizioni bioclimatiche. - Mem. Biogeogr. Adriatica, V: 53-118; Venezia.

Marcello, A. \& Comel, A. (1963): L'alluvione che seppelli Julia Concordia. - Mem. Biogeogr. Adriatica, V: 139-154; Venezia.

- \& Spada, N. (1968): Notizia di una vicenda climatica antica nella Laguna di Venezia. Mem. Biogeogr., Adriatica, VII, Suppl.: 43-49; Venezia.

Murray, J. W. (1971): Living foraminiferids of tidal marshes: a review. - J. Foram. Res., 1, 4: 153-161; Washington.

Pirazzoli, P. (1973): Inondations et niveaux marins à Venise. - Mém. Lab. Géomorph. E.P.H.E., 22: 284 p.; Dinard.

- (1974): Dati storici sul medio mare a Venezia. - Atti Accad. Sci. Ist. Bologna, Rendiconti, XIII, I: 125-148; Bologna.

- (1978): Bathymétrie et turbidité dans la lagune de Venise. - Photo Interprétation, 3: 1724; Paris.

Polli, S. (1950): Costanti armoniche e non armoniche delle maree di 4 località della laguna di Venezia (Paliaga, Torcello, Torson di Sotto, Millecampi). - Archivio Oceanogr. Limnol., VII, 1: 17-27; Venezia. 
